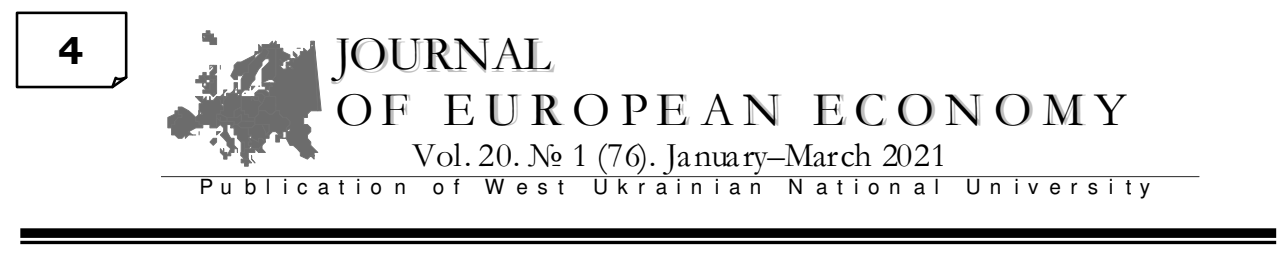

Economic Theory

\title{
Oleksandr SHAROV
}

\section{HISTORIOSOPHICAL ASPECTS OF THE MONETARY GLOBALIZATION}

\begin{abstract}
This article is devoted to the monetary globalization - it is a concept that was at first designed and introduced in academician use by the author in the previous article (Journal of European Economy, vol. 19, No. 3, 2020, pp. 395-408). While the first article considered its geoeconomic aspects - namely the geographical spreading and universalization of the monetary relations, this article focuses on historiosophical aspects - that is, understanding the patterns of development of monetary relations in the context of their globalization. It is emphasized that the emergence of money occurred near simultaneously in different civilizations and the European model was not predestined to become a standard for the world monetary system, but its superiority was ensured in the complex centuries-old globalization process. This concerned not only the formation and spread of monetary relations in the world, but also their universalization, which played a very important role in economic globalization. In this regard, the author points to the role of the state, especially in the last stages of globalization, starting with the formation of the gold standard in the $19^{\text {th }}$ century and ending with the introduction of the Bretton-Woods monetary system and modern processes of its modernization.
\end{abstract}

(C) Oleksandr Sharov, 2021.

Sharov Oleksandr, Doctor of Economic Sciences, Professor, Senior Researcher at Institute for Economics and Forecasting of the National Academy of Sciences of Ukraine, Kyiv, Ukraine. ORCID: 0000-0001- 8460-9996 Email: osharov@niss.gov.ua. 


\section{Key words:}

central banks; chrimatogenes; destuffing of money; globalization; monetary relations; monometallic standard.

JEL: E42, E52, F59, N20.

27 References.

A weak currency is the sign of a weak economy, and a weak economy leads to a weak nation.

Ross Perot

\section{Literature Review and Problem Statement}

The aim of the article is to consider the historiosophical aspects of the new concept of «monetary globalization», which is defined as a general historical trend of money development in the direction of internationalization and transformation into a global equivalent value of all goods due to the disappearance of borders.

As is quite fair, from our point of view, the well-known British professor B. Jessop notes, "Globalization is not a singular cause-and-effect mechanism with a universal unitary logic. It is an extremely complex result of many events, processes and transformations that is constantly evolving; the result is polycentric, multilevel, polytemporal and polymorphic. Therefore, while acknowledging that for many, though by no means for all firms, financial instruments and capital fractions, it has become easier to act in real time globally, it should be noted that there are important points of succession with historically previous waves of mar- 
ket integration" (Jessop, 2019, p. 354). Therefore, the current state of monetary globalization can be understood only by analysing the course and impact of its previous stages.

In fact, economists have to deal with the explanation of history quite often lately (Zaostrovtsev, 2019, p. 99). This applies in particular to the work of two American researchers - Douglass Cecil North and Robert Fogel, who in 1993 received the Nobel Prize in Economics «for having renewed research in economic history by applying economic theory and quantitative methods in order to explain economic and institutional change» (North, n.d.; Fogel, n.d.). Among the more modern works is the book "Violence and Social Orders» of that same D. North (co-authored with other scholars) (North et al., 2009) and essays on the economics of history of S. A. Skorobagatov (2018). However, both D. North and S. A. Skorobagatov in their works pay much attention to the economics of gift and trade, which cannot be said, unfortunately, about money and money relations.

Numerous journal publications are also devoted to the problems of the economics of history, including one by S. Hedlund (2006), which however, only emphasizes the complexity of combining the work of economist and historian as its author without hesitation proclaims Vladimir the Great to be Prince of Muscovy (which did not exist for more than two centuries after his death) in order to justify the economic policy of Russia under Yeltsin and Vladimir Putin (for whom, it seems, Vladimir the Great was needed in the first place).

As for the history of monetary relations, two economists who have devoted their work to this issue should be noted foremost, namely R. Mundell (2002) and his study of the history of coinage in ancient times, and American professor L. R. Wray - best known for his book «Modern Money Theory» (2015) - and a study he conducted jointly with one of the graduate students on alternative money history (Tymoigne \& Wray, 2007), as well as his later work on the same issue (Wray, 2012).

\section{Research Results}

Our research is also, to some extent, devoted to explaining the history of money in terms of the development of global economic processes, which they directly affected. However, the history outlined below seems to be a slightly different story than it is in the textbooks that follow the evolutionary theory, one where the passage of time is reflected in the development from simple barter to equivalent goods to a monopoly equivalent (gold and silver). Ours is a more complex process, which was influenced not only by economic factors, and which, in turn, influenced the general social development. 
According to archaeological research, money did not evolve from barter (as it seemed to the classics), but from the relationship caused by the gift economy. Starting with ritual exchanges of gifts, «as society develops 1) there is a separation of economic and social relations, 2) increasing separation of resources of individual households from each other and from community resources, 3) increasing importance of personal gain in motivation and actions of people, 4) personal ties give way to depersonalized contacts, 5) increasing requirements for the equivalence of exchanges and their counter-nature increase" (Butorina, 2016, p. 129). That is, «the market economy has very gradually grown in the depths of the gift economy. Barter, it seems, never was an economic system that included the whole of society». (Butorina, 2016, p. 129).

Incidentally, the exchange of gifts, especially among the princes, provided the transfer of a large amount of material wealth in Kyiv (Noonan, 1987, p. 386).

Barter agreements, of course, existed (as they do now), but they hardly ever played a decisive role in meeting the economic needs of society. Thus, the focus of scientific research on the functions and role of such an «agent» (i.e., government) contributes to a better understanding of the processes of chromatogenesis and global monetization.

At the same time, it is noteworthy that just as the Western leadership in globalization was not predestined, so could monetary globalization have developed from any of the three civilizational centres of humanity - the Dharmic (Hindu-Buddhist), Taoist-Confucian or Abrahamic - because money as a civilizational innovation appeared almost simultaneously and independently in each of these centres. However, their future development occurred in accordance with the laws of economic development of the respective civilizations.

Dharmic or Hindu-Buddhist (for all the differences within such a conglomerate) civilization revolves around the individual, their spirituality, sometimes openly neglecting the organization of their earthly life.

Taoist-Confucian civilization, on the other hand, focuses primarily on nature, requiring the individual to adapt to the «laws of nature» (including the «natural» laws of state power). Their ideal is not freedom as a goal in itself (they did not know this concept until they translated into their language the term that came to them from the West in the late nineteenth century), but spontaneity, which is consistent with their analysis of process logic (Rius, 1998, p. 249).

Both approaches, however, seem flawed because they ignore the cumulative effect of combining the individual and nature, spiritual and material. This combination is more typical of civilizations based on Abrahamic religions - Judaism, Islam and Christianity. This strand cultivated such opposing avenues of human thought as liberalism and Marxism. "In both cases, the substitutes of «nature» forbid arbitrary interference, demanding compliance with their own laws. The «invisible hand» of the market echoes the cunning of historical reason. 
(...)These complex games of sovereign "activity» and managerial «passivity", which unfold differently at two different levels, reveal a single sovereign «theological-economic» source» (Kobylin, 2020, p. 103).

The development of the ancient economy resulted in not just the invention of the Hellenistic form of money, but their dominance in the world. While in the Hindu-Buddhist tradition money remained only a sacred invention and part of spiritual practice, only Hellenistic influence contributed to the development of money on Hindustan, practically starting from scratch, as previous Buddhist practice proved pointless and lost touch with economic practice.

Within the framework of the Taoist-Confucian civilization, money developed quite dynamically in accordance with the needs of the «natural laws of state power». However, Chinese money did not spread beyond China. According to the "Needham paradox», these achievements (in particular, the idea of paper money) were widely used outside of this civilization, namely in the depths of Abrahamic civilization where their globalization began.

After all, according to Israeli scientist D. Schaps, the invention of the coin was not just a technological invention, but also a conceptual revolution. The concept of «money» clearly materialized in history only with the invention of the ancient Greek coin. The coin appeared at a time when there was a significant need for such a tool in Hellenistic society, which in some respects led to rationalization and social equalization, while creating new illusions, paradoxes and elites (Schaps, 2010). It was the ancient Greeks who came up with the idea of monetiz-

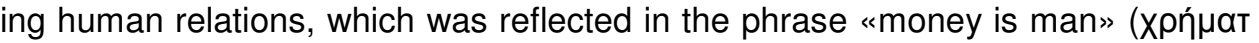
'ávńp). In general, it seems that the permeation of money (minted coin) into the life of Hellenistic society was quite slow. Researchers point out that philosophers did not mention the impact of coins on life and customs for two hundred years since the first ones were minted (Kurke, 1995). Only Herodotus (484-413 BC) in his History writes (166-CLXVI) about the punishment of Ariandus, the prefect of Egypt, for minting silver «darics» (Herodotus, 430/1993, p. 201), and later only Aristotle (after another hundred years) considers the influence of money in detail in his Politics.

Thus, globalization of monetary relations has significantly affected not only economic but also political systems - both in the pre-modern and in subsequent eras. The directions of cash flows, if not determined, significantly contributed to the emergence of not only ancient and overseas colonies of modern times, but also entire empires, such as the spread of the empires of Alexander the Great or Genghis Khan (who spread their power from different sides of the Great Silk Road). One of the clearest examples of such influence could also be observed on the territory of modern Ukraine, where the flows of Arab silver went to the north of Europe bypassing the middle Dnieper until the «first silver crisis» of $875-880$ forced the Rus' to seek out the trade route «from the Varan- 
gians to the Greeks», which required the development of a trading centre in Kyiv, and later an entire state.

The early modern period began with the end of the Middle Ages (the spread of firearms, which ended the time of the knights and the bourgeois revolution in the Netherlands), the surge of scientific knowledge (Copernicus, Galileo, etc.) and geopolitical changes (the fall of Constantinople, the discovery of America and the Age of Exploration). However, it also saw the first Great Inflation in Europe, which was the result of combining the unrealized monetary potential of the New World with the developed system of monetary relations of the Old World.

In the modern age, monetary relations as a tool of social technology played an important role not only in deepening economic relations within societies that actively used them (European, Arab, Hindu and Far Eastern), but also in the spread (globalization) of economic relations to other countries and regions. That is, successful colonization was built on technological advantages not only in technical but also in socio-economic sense. Here, money played as significant a role as gunpowder, ships or the steam engine.

After the spread of monetary relations to all inhabited continents (global monetization), the question of unifying monetary systems was first on the agenda. Once again, Europe claimed leadership in this process. After all, even the Latin couplet of the Roman Empire times went: "Una fides, pondus, mensura, moneta sit una; Et status illaesus totius orbis erit» («A single faith should be a single weight, measure, and money; And the state of all the world will be healthy»). Renerus Budelius used these lines as an epigraph to his work $D e$ Monetis, Et re Numaria (which was published in 1591 and became a classic work of coinage for the next two centuries). However, the Romans meant monetary unification only in their own empire, and R. Budelius called for the unification of coins within the German lands (which at that time were divided between many kingdoms, duchies, electorates, free cities and dioceses (one of which was located around the city of Roermond, the mint of which was headed by R. Budelius). The general thesis of Budelius was that trading partners should seek to use only one currency. During the Cologne War (1583-1588), Germany had several different currencies and coinage laws, and this not only hindered domestic trade in Germany, but also led to armed conflict, which led to even greater fragmentation of the economy. So, Budelius's work can be seen as an attempt to unite Germany (and the rest of Europe) through one currency. In this respect, R. Budelius differs not only from medieval researchers in the field of money circulation (who supported monetary nationalism), but also from his contemporaries, the mercantilists. In essence, his work is a synthesis of two traditions. On the one hand, the possibility of fiduciary money is asserted (R. Budelius speaks of the sovereign's right to mint money «be it from leather, be it from salt or any material so long as he can honestly reimburse his subjects»). On the other hand, it re- 
veals the practical usefulness of the universalization of money circulation as a means of increasing income in emergencies.

Nonetheless, where R. Budelius was concerned with the idea of a single currency for only German lands, the treatise published almost a decade earlier (in 1582) of an Italian economist and money changer G. Scaruffi (1519-1584) proposed a universal common European currency to create an open, objective and fair economic system, which, in his opinion, was the basis of a just society. Based on his experience as a financier and mint manager, as well as knowledge of the practices of various Italian states, he was convinced that the number and variants of coins in circulation, as well as arbitrary practices such as devaluation, only hindered trade.

To solve these problems, he proposed a currency whose value would be universal because it would be based on the intrinsic value of its precious metals content. G. Scaruffi published his ideas in a book called L'Alitinonfo (ancient Greek - «True Light») (Graziani, 1913). This is how he proposed to name the universal currency, which would be the basis of a society based on objective actions that followed natural law. In Alitinonfo, the argument for a universal system of coinage based on intrinsic value not subject to the whims of princes or merchant agreements becomes a metaphor for the economy and society based on universal standards of objectivity and justice. It is not entirely clear how much his ideas influenced other economists, but his views were a notable step forward from mercantilism to a more modern economic concept. As for the practical consequences, they had to wait a bit. At this stage of globalization, the unification of money circulation was achieved by establishing a monometallic standard.

The classical period of the gold standard lasted from 1880 to 1914 . The first part of this period was characterized by the slight fall in commodity prices as more countries joined the gold standard, and, as a consequence, sought to accumulate gold reserves. This increased the demand for gold almost all over the world. Of course, an integral part of the gold standard was also the rise in price of gold compared to other commodities against the backdrop of falling general prices, which in turn stimulated the search for new gold. The discovery of new gold deposits in the 1890s in Australia and America helped reverse the trend and prices began to rise slightly.

The key problem, however, was that the implemented system of the gold standard from the very beginning was «infected» by the system of credit issue. In other words, the gold standard carried the seeds of a new system - the system of credit money - due to its mechanism containing such an institution as the central bank.

Thus, we can conclude that at this stage of globalization, the modernization of the monetary system occurred with the participation of the state. However, while in the days of pre-modern globalization the state only «pushed» these 
processes, giving them the appropriate form, now the state was directly involved in the introduction of more innovative forms of money circulation, «tailoring» them to market requirements.

One such attempt was the partial return to the gold standard. This was significant not because it tried to return to the old, proven principle of issuing gold money, but because Genoa Conference introduced one of the fundamental principles of the modern credit monetary system - the principle of «depoliticization of money", according to which the issuance of money should be carried out in accordance with the needs of the economy, rather than political expediency.

Another important point was that monetary reforms could be successful only if the central banks of different countries cooperated, and that there was a single standard for all (at least European) monetary systems, which at that time could only be gold. Therefore, the inflexibility of such a basis required a search for new principles of building the global monetary system. Such principles, found in Bretton Woods, have significantly changed the order of central banks in the monetary sphere. Now issuing banks create national money on the basis of dollars that come to them during the payment of the US balance of payments deficit and send this money to debt holders from US counterparties, while reinvesting most of the dollars received in the US financial market. In this way, as noted at one time, the famous French scientist Prof. J. Rueff, «The United States no longer had to settle this share of its deficit with other countries. Everything happened on a purely financial plane, as if there was no deficit at all. The goldcurrency standard thus revolutionized world finance and gave birth to the secret of the deficit without tears. This mechanism allowed countries that issued currency with international prestige to give without withdrawal, to lend without borrowing, to acquire without payment» (Rueff, 1972, p. 23).

The transition to the gold-currency (and eventually to the gold-dollar) standard has led to three fundamental consequences.

First, the balance of payments deficit ceased to affect aggregate purchasing power (which automatically occurred under the gold standard due to the physical transfer of monetary goods - gold - abroad).

Second, within such a system, each payment deficit of the country issuing a reserve currency leads to a doubling of the world credit base. Thus, when capital is returned to the countries from which it came (in calculations of the balance of payments) there is a possibility of a credit boom in «deficit» countries without a recession in «surplus» countries.

Third, the new system leads to the erroneous credit structure, which occurs as a result of «double mortgage» on most gold reserves of the issuing country of the reserve currency (Rueff, 1972, p. 24-28). 
At the same time, in response to the demands of growing production of goods and trade, the principle of money issuance begins to change: the minting of even expensive gold coins can no longer meet economic needs and industrialized countries are moving to printing paper banknotes of central banks.

The emergence of a fundamentally new issuing institution - central banks - became an important and, to some extent, determining factor in the further evolution of monetary relations. Moreover, the first central banks were created as special commercial banks, rather than public financial institutions not focused on maximizing profits in their activities, which they were transformed into much later. In any case, these were quite special institutions, which were not only the main bankers of the government, but also received privileged licenses, especially for banknote issuance. In many cases, particularly in the Nordic countries, the Netherlands or Austria-Hungary, the right to issue banknotes was granted to them in the form of a monopoly (Capie et al., 1994, p. 4).

Eventually, two major issuing institutions were formed under the new monetary mechanism: 1) central banks characteristic of metropoles - with discretion to issue on the basis of monetary sovereignty; and 2) currency bureaus characteristic of colonies - whose issuance right was based on reserve requirements and essentially dependent on external management (even if the bureau was not subordinated to foreign central banks or other monetary authorities).

On the other hand, the state claimed the right to issue money through its fiscal authorities either in the form of direct issuance of treasury bills, or by direct commitment of central banks to repurchase short-term government debt (bonds, etc.). This not only entrusted the central bank with the functions of a "government bank», but in fact created two decision-making centres for the issuance of money. This state of affairs began to change only in the post-war years (U.S. Treasury-Fed Accord of 1951), but it took another two decades before the abandonment (and even the statutory ban) of direct lending to governments by central banks became the norm.

Thus, further development of the world monetary system followed the German example, that is the central bank's monopoly on the issuance of paper banknotes, which eventually only restored the issuance status quo ante - the right of monetary regalia in the new conditions was transformed into a monopoly right to issue credit money.

Of course, these changes could not and did not go unnoticed, by either the monetary authorities of individual countries or by the centre of the world monetary system - the International Monetary Fund, which is currently one of the largest (188 member countries) and most well-known international organizations. Created to manage a system of fixed exchange rates in which all currencies were effectively pegged to the US dollar, the Fund was forced to seek a raison d'etre of its continued existence in the new conditions. 
This a meaning was found in the need to coordinate actions to ensure the financial stability of the world. Letting the genie out of the bottle in the form of free movement of capital, the financial world created the greatest threat to its stability. Macroeconomic indicators could no longer serve as warning signs of impending crises: the latter occurred as a tsunami and just as suddenly (in terms of old economic views) were transmitted through the financial market to remote parts of the world.

Thus, objectively, there was a need to establish «permanent monitoring stations» and an "operational response centre». Thus, in historical perspective, the inching demonetization of gold is one of the differences between globalization in the period 1870-1914 and our times. The gold standard was based on the principle of fixed currency parities and was therefore a sine qua non of the mechanism of large-scale international investment. Modern financial globalization is happening in times of significant exchange rate volatility and therefore requires only small gold reserves (Ferguson, 2002, p. 321).

Technological changes in the world monetary system were added to the sectoral, functional and institutional ones.

The idea of digitizing money circulation is based on previous developments in this field, which aimed at overcoming the shortcomings of cash circulation. While in corporate, "wholesale" circulation this could have been done a long time ago by simple bank entries in customer accounts, in «retail» circulation it has long been a problem, because the replacement of the «ringing coin» with paper money, including banknotes, bills or checks only simplified problems, but did not solve them until credit cards appeared.

The history of bank cards dates back to 1946, when Flatbush National Bank of Brooklyn organized the Charge-It credit scheme, which included reports received by local stores from customers for small purchases. After the purchase, the store sent these reports to the bank, which paid them from the accounts of customers (Frishberg, 2016). The first mass payment card («Diner's Club») was created in 1949. Then, along with the development of the United States market, card transactions began to spread quickly and soon (late 1950-1960) appeared such well-known payment systems as Visa, MasterCard and American Express. Initially, the use of bank cards required anachronistic technology with sending reports by mail. However, in the late 1960s, a special commission was set up in the United States to develop «paperless» accounting, whose purpose was to develop principles for automated clearing houses. In 1978, the United States launched its own electronic money transfer system.

At the same time, the original forms of bank transactions were developed through personal computers - home banking systems (for private clients) and firm banking systems (for corporate clients). In 1984, there were only two large (for that time) home banking systems in the United States, created by Bank of America $(8,000$ customers) and Chemical Bank $(5,000)$. In a year, the number of 
customers increased significantly and new competitors appeared. This is understandable, because as the above-mentioned prof. D. Chorafas noted, «Technology is a demanding partner. Like Alice in Wonderland, we have to run for all our worth just to stay in the same place» (Chorafas, 1982, p. 236). In reality, all banks are interested in improving their standing. For that, they had to constantly improve their technology. The technical basis of a more advanced form of electronic banking was the "videotext» system, which was a network of channels for electronic distribution of video information transmitted to TV screens or PC displays that were installed at customers' homes. This system was pioneered by library centres and news agencies, but soon the innovation was introduced in banks as well.

The era of «electronic money» or, as we then proposed to call it, the "destuffing" (Sharov, 1986, p. 87) of money, that is the disappearance of the material form of means of circulation and payment. In almost two decades, this phenomenon has reached such proportions that it has become possible to state that in the course of the ongoing evolution of money, it seems that the dollar will eventually become an abstract unit of currency without a specific embodiment in metal or paper. This shift towards abstract currency will be complicated even further by the evolution of regional and global markets (Khan, 1998, p. 419).

At the same time, the interdependence of foreign exchange markets has increased significantly with the development of communication means and information processing. The emergence of nationwide payment systems that operate in real time (Real Time Gross Settlement - RTGS), and later their connection, essentially, in international financial networks (such as the EU system TARGET) strongly affected functioning of the world monetary system. After all, now the rules of currency regulation and control must take into account the possible impact of operations not only on the national economy. Consequently, the impact of transactions in geographically remote markets should be taken into account. In fact, this dependence was demonstrated by the crisis of 1997-98, which spread with the speed of the "coronavirus» from Southeast Europe to Latin America and Russia.

\section{Conclusions}

Historical analysis shows that money has played a significant role in the process of economic globalization, in particular:

1) has created a common meaning for economic activity by creating a single economic paradigm based on the value of products (goods) which it measured, as the monetary expression of value became the economic lingua franca» that different markets used to communicate with each other; 
2) has become a universal tool for the development of trade and credit relations around the world by acting as a means of circulation and payment;

3) has become a universal stimulus (incentive) to finding new markets and suppliers, development of new trade routes, major geographical discoveries, economic integration and, finally, economic globalization itself;

4) last but not least, has become a state-building element, which was, if not decisive, then at least important in the process of emergence, development and strengthening of many states. In this regard, in addition to the above examples, noteworthy is the role that factors such as the Bretton Woods gold standard, dollar famine, Triffin dilemma, emergence of Eurodollars and dollarization of individual economies played in establishing modern financial and economic power of the United States. That or the role that the creation of the Euro as a collective currency played in supporting the European Union's leadership in the world and its movement towards becoming the «United States of Europe».

All these processes that occurred both in the markets of individual countries or small regions and at the international level (where money's function as global currency started almost immediately after its emergence) constitute the essence of monetary globalization.

Considering monetary globalization from the standpoint of today, we can say that metal money was quite immanent to the pre-modern period with its hereditary (personal) sovereignty of monarchs and trade (exchange) economy. Instead, early modern era, with nation-states and industrial development, required fiat money (not tied to the value of the substance from which they were made). Finally, late modern era, with a global network of supranational alliances and post-industrial economy, requires even more flexible monetary systems based on electronic information transfer technologies.

If we adhere to the moderate anti-evolutionary version of the historical dynamics of A. Giddens (1984), it is admittedly impossible to explain the development of society by the biological model of evolution, according to which new species simply replace the old. In social development (including its economic component), the new mainly does not replace the old, but builds upon it (according to the Hegelian principle of dialectical negation). In fact, we could see this process in the evolution of monetary relations in the process of globalization, when various forms of money (gold, commercial bank notes, central bank notes, fiduciary / fiat money, electronic money) do not disappear replaced by new ones, but remain while giving priority to new forms, more adequate to the updated conditions of economic life. Therefore, the accumulation of experience is accompanied by a change in the ratio of structural components and their importance for the functioning of the whole mechanism.

Thus, it can be argued that monetary globalization - including such phenomena as spread of monetary relations, universalization of monetary systems of 
payments, use of foreign currency in national circulation, free conversion of currencies and liberalization of international money flows - has created the necessary preconditions for economic globalization, which, in turn, was one of the driving forces of the overarching globalization process.

\section{References}

Butorina, O.V. (2016). On Origin of Money [In Russian]. Contemporary Europe, 3, 124-135.

Capie, F., Fischer, S., Goodhart, Ch., \& Schnadt, N. (1994). The development of central banking. In F. Capie, S. Fischer, Ch. Goodhart, \& N. Schnadt (Eds.), The future of central banking: The tercentenary symposium of the Bank of England (pp. 1-112). Cambridge University Press.

Chorafas, D. N. (1982). Money--the Banks of the'80s. Petrocelli Books.

Ferguson, N. (2002). The cash nexus: Money and power in the modern world, 1700-2000. Basic Books.

Fogel, R. W. (n.d.). Biographical. Nobel Prize Outreach. https://www.nobelprize.org/ prizes/economic-sciences/1993/fogel/biographical/

Frishberg, H. (2016). The origins of the credit card trace back to a flatbush bank. Brownstoner. https://www.brownstoner.com/history/bank-credit-card-brooklynflatbush-national-bank-history/

Giddens, A. A. (1984). Contemporary critique of historical materialism. Vol.2, the nation state and violence. Polity Press.

Graziani, A. (1913). Economists of the sixteenth and seventeenth centuries [in Italian]. Gius, Laterza \& Figli. https://archive.org/stream/economistidelcin 00grazuoft\#page/378/mode/2up

Hedlund, S. (2006). Vladimir the great, Grand Prince of Muscovy: Resurrecting the Russian service state. Europe-Asia Studies, 58(5), 775-801.

Herodotus. (1993). Histories (A. Biletskyi, Trans.) (Vol. 4) [in Ukrainian]. Naukova dumka. (Original work published ca. $430 \mathrm{BCE}$ )

Jessop, B. (2019). The State: Past, present, future [in Russian]. Delo.

Khan, A. (1998). The evolution of money: A story of constitutional nullification. University of Cincinnati Law Review, 67: 393.

Kobylin, I. (2020). Details of the explosion: semiotics, synergy and the "oeconomics" of history [in Russian]. Neprikosnovennyi zapas, 1, 97-110.

Kurke, L. (1995). Herodotus and the Language of Metals. Helios, 22(1), 26-64. 
Mundell, R. (2002). The Birth of Coinage. Department of Economics Discussion Papers, 0102-08. Columbia University.

Noonan, T. S. (1987). The monetary history of Kiev in the pre-Mongol period. Harvard Ukrainian Studies, 11(3/4), 384-443.

North, D. C. (n.d.). Biographical. Nobel Prize Outreach. https://www.nobelprize.org/ prizes/economic-sciences/1993/north/biographical/

North, D. C., Wallis, J. J., \& Weingast, B. R. (2009). Violence and social orders: A conceptual framework for interpreting recorded human history. Cambridge University Press.

Rius, J. (1998). Advance of Modern Ideas [in Ukrainian]. Osnovy.

Rueff, J. (1972). The monetary sin of the West. Macmillan Company.

Schaps, D. (2010). The invention of coinage and the monetization of ancient Greece. University of Michigan Press.

Sharov, A. N. (1986). Development of the banking technology [In Russian]. SSHA: ekonomika, politika, ideologiya, 9, 85-92.

Skorobagatov, S. A. (2018). The society as a treaty between the strong and the weak. Essays on the economics of history [in Russian]. VShE.

Tymoigne, É., \& Wray, L. R. (2007). Money: An alternative story. In Ph. Arestis \& M. (Eds.), A handbook of alternative monetary economics (pp. 1-16). Edward Elgar Publishing.

Wray, R. L. (2012). Introduction to an alternative history of money. Working Paper No. 717. Levy Economics Institute of Bard College.

Wray, L. R. (2015). Modern money theory: A primer on macroeconomics for sovereign monetary systems. Springer.

Zaostrovtsev, A. (2019). On strong and weak in the economics of history. Contemplation on the book [in Russian]. Social Sciences and Contemporary World, 4, 99-108. https://doi.org/10.31857/S086904990005818-1 